\title{
Cultural adaptation of the Family Management Measure among families of children and adolescents with chronic diseases ${ }^{1}$
}

\author{
Carolliny Rossi de Faria Ichikawa ${ }^{2}$ \\ Regina Szylit Bousso ${ }^{3}$ \\ Maira Deguer Misko ${ }^{4}$ \\ Ana Marcia Chiaradia Mendes-Castillo ${ }^{5}$ \\ Estela Regina Ferraz Bianchi ${ }^{3}$ \\ Elaine Buchhorn Cintra Damião6
}

Objectives: to perform the cultural adaptation of the Family Management Measure into the Brazilian Portuguese language. Method: the method complied with international recommendations for this type of study and was composed of the following steps: translation of the instrument into the Portuguese language; reaching consensus over the translated versions; assessment by an expert committee; back translation; and pretest. Results: these stages enabled us to obtain conceptual, by-item, semantic, idiomatic, and operational equivalences, in addition to content validation. Conclusion: the Family Management Measure is adapted to the Brazilian Portuguese language and that version is named Instrumento de Medida de Manejo Familiar.

Descriptors: Family; Pediatrics; Chronic Disease.

\footnotetext{
${ }^{1}$ Paper extracted from master's thesis "Cultural Adaptation of Family Management Measure for families of children with chronic illness", presented to Escola de Enfermagem, Universidade de São Paulo, São Paulo, SP, Brazil.

${ }_{2}^{2}$ MSc, Assistant Professor, Centro de Ciências da Saúde, Universidade Estadual de Londrina, Londrina, PR, Brazil.

${ }^{3} \mathrm{PhD}$, Associate Professor, Escola de Enfermagem, Universidade de São Paulo, São Paulo, SP, Brazil.

${ }^{4} \mathrm{PhD}$, Professor, Universidade Federal de São Carlos, São Carlos, Brazil.

${ }^{5}$ Post-doctoral fellow, Escola de Enfermagem, Universidade de São Paulo, SP, Brazil.

${ }^{6} \mathrm{PhD}$, Professor, Escola de Enfermagem, Universidade de São Paulo, São Paulo, SP, Brazil.
}

Corresponding Author:

Carolliny Rossi de Faria Ichikawa

Rua Otávio Palhares, 242

Jardim Santos Dumont

CEP: 86039-710, Londrina, PR, Brasi

E-mail: caroll-rossi@hotmail.com
Copyright (c) 2014 Revista Latino-Americana de Enfermagem This is an Open Access article distributed under the terms of the Creative Commons Attribution Non-Commercial License (CC BY-NC).

This license lets others distribute, remix, tweak, and build upon your work non-commercially, and although their new works must also acknowledge you and be non-commercial, they don't have to license their derivative works on the same terms. 


\section{Introduction}

Chronic diseases are of long duration and usually progress slowly. Cardiac diseases, strokes, cancer, chronic respiratory diseases and diabetes are, by far, the main causes of mortality around the world and accounted for $60 \%$ of all deaths in $2005^{(1)}$.

Currently, it is estimated that from $20 \%$ to $30 \%$ of children and adolescents in the United States suffer from some chronic disease or chronic health condition. These conditions may affect children over the course of their lives, also affecting the family unit( ${ }^{(2)}$. Increased care that is required daily, the complex activities needed to manage the disease, the lifestyle and dynamics of the family and of each of its members, may affect health outcomes in the long run ${ }^{(2)}$.

The presence of a chronic condition during childhood or adolescence affects the patient's existential dimension and involves various facets. It may affect the individual's social participation, education, sports practice, leisure, relationshipswithfamilymembers, groupsandinterpersonal relationships, the family's financial status, and also its future planning(2-5).

The family is an important element in the health care of children with chronic diseases and should be considered a partner of the health staff since it is directly responsible for the child or adolescent. The family of a child with a chronic condition has to deal with irreversible changes after the disease, which requires continuous management. For complete success in that, families need to seek the meaning of the disease in their lives and identify their perceptions and behaviors related to the experience with the objective to maintain life(6).

The nursing staff needs to acknowledge the family's situation, how the family deals with stressful situations, how it copes with the demands of the disease, and what type of resources it can access ${ }^{(7)}$, in order to support and promote the health of both the child and the family.

The Family Management Style Framework (FMSF) was developed by Kathleen Knafl and Janet Deatrick in 1990 as a model to understand how the family unit incorporated the demands of the child's condition within family life. Afterwards, they expanded the model to promote a theoretical structure, defining behavior patterns so that they would be more efficaciously assessed, generating interventions in the most varied contexts in order to meet the demands of families ${ }^{(8-10)}$.
Interest in identifying the different styles of family management in the most varied situations of diseases and with differentiated approaches has grown in recent years. The expression "family management style", though little known in the Brazilian context, has been frequently used in the international literature to refer to a relatively consistent pattern used by the family to respond to a family member's condition. The term "management" reinforces the focus on the behavioral, active element of the family response, differentiating it from other components of family dynamics, such as communication and decision-making(10-11).

The importance of establishing patterns and profiles of family management has led many researchers to conduct typological studies in order to provide tools for health professionals implementing personalized interventions for these families ${ }^{(8,10-12)}$. These studies related to family management raise a new demand: the supply of tools to both researchers and professionals providing care. Despite the large number of alreadyestablished instruments to measure family processes in general (communication, decision-making, coping, resilience), there were no instruments available to identify the family management of diseases, and the incorporation of disease and treatment regimen into the family life.

Therefore, based on the model previously presented, these same authors developed the Family Management Measure (FaMM), which is an instrument that measures family management, addressing the way the family deals with a child with a chronic disease. It is composed of 53 items divided into six scales: five scales can be answered by either the child's father or mother and measure the following dimensions: Child Identity, Management Ability, Management Effort, Family Life Difficulty, and View of Condition Impact. The sixth scale, applied only when both parents are present during the interview, measures the dimension Parental Mutuality ${ }^{(12)}$.

This instrument is reliable and applicable in the American context and is currently being applied in different contexts of disease ${ }^{(10,13)}$. The test of the FaMM's psychometric properties was based on data from 579 parents of children with chronic diseases; strong reliability and validity support all the six dimensions ${ }^{(12-13)}$.

In Brazil, there is a lack of instruments measuring family management in the context of chronic child diseases. Hence, this study's objectives were to 
culturally adapt the Family Management Measure (FaMM) into the Brazilian Portuguese language and test the reliability of the adapted version, checking for the internal consistency of its items in a sample of families of children and adolescents with chronic conditions.

\section{Method}

This quantitative study used the methodology proposed by Guillemin for the translation and crosscultural adaption of instruments, which consists of the following process: asking permission of authors to culturally adapt and validate the Family Management Measure (FaMM); translate the FaMM into Portuguese; reach the first consensus over the translated versions; assessment by an expert committee; back translation; pre-test; and data treatment ${ }^{(14)}$.

\section{Choice of the instrument}

FaMM was chosen because it is an instrument that measures family management, that is, it is a scale that assesses how the family deals with a sick child. The main motivation for the choice was the fact that there is no similar instrument in Brazil. Authorization to validate the instrument was sought through the site http://nursing. unc.edu/research/famm/ and also through e-mail with the primary author, Dr. Kathleen Knafl, who also helped the entire process in order to achieve an adaptation as close as possible to the original version.

\section{Procedures}

Two Portuguese versions of the original instrument were translated by translators fluent in both languages. One translation was performed by a health professional who knew the study's objectives and the other translation was performed by an expert in the English language who was not aware of the study's objective (blind translation). Then a consensus was reached among this study's authors on the Portuguese version (PV1). The PV1 was assessed by an expert committee composed of: three experts on chronic child disease; three experts in the cultural adaptation of instruments; and three family members of children with chronic diseases. The purpose of this committee was to assess the translated instrument in regard to the conceptual, by-item, semantic, idiomatic and operational equivalence and equivalence of its content validity.

After the expert committee's assessment, the second version was developed (PV2). The PV2 was sent to two translators whose country of origin was the same as the instrument's in order for them to translate this version into its language of origin. The authors reached the instrument's final version based on the analysis of the back translations.

In the second stage, the adapted instrument was applied to a sample of 72 family members of children and adolescents with chronic disease. The purpose of this test was to assess the adapted instrument's internal consistency for items and dimensions before the validation process was initated. A convenience sample was used. The family members answered the adapted FaMM, analyzing comprehensibility and the clarity of items. The participants accompanied their children in outpatient care of a public university hospital in the city of Londrina, PR, in the South of Brazil. The interviews were held from June to August, 2011. Inclusion criteria were: families of children and adolescents up to 18 years old, with chronic diseases, signing free and informed consent forms. The respondent should be a family member, live in the same household as the child and participate in the child's care.

The study was approved by the Institutional Review Boards at the University of São Paulo (Process No. $887 / 2010$ ) and the State University of Londrina (Process No. 031/2011) in accordance with Resolution 196/96, National Council of Health(15)

\section{Data analysis}

Reliability was verified through Cronbach's alpha, a coefficient used to assess an items' internal consistency. This coefficient assesses the extent to which all the instrument's subparts measure the same characteristic. The indexes range from 0.00 to 1.00 and the higher the reliability coefficient, the more accurate (internally consistent) the measure is ${ }^{(16)}$; a coefficient of 0.7 was considered satisfactory in this study. Descriptive statistics were used both to characterize the sample and to compute frequencies, proportions, means, standard deviations, and minimum and maximum values. The level of significance adopted was $5 \%$. 


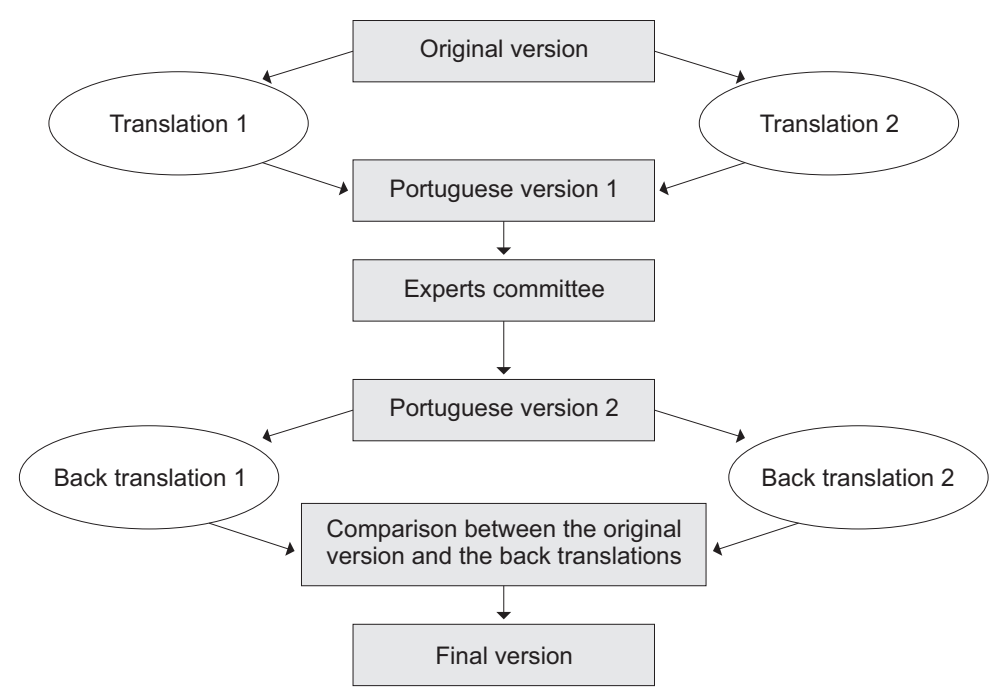

Figure 1 - Etapas do processo de adaptação cultural do Family Management Measure

\section{Results}

Stage 1, which comprised the FaMM adaptation process, included the translations, synthesis of the translations performed by this study's authors and development of the Portuguese Version (PV1), which was sent to be assessed by an expert committee. This assessment was initially performed through e-mail. The experts assessed the adapted instrument's conceptual, by-item, semantic, idiomatic and operational equivalences. Inter-rater agreement of $80 \%$ was not achieved in relation to the semantic and idiomatic equivalence. For this reason, a meeting was arranged with the presence of all the experts and consensus of $100 \%$ was achieved in all the equivalences. The primary author of the original instrument, Dr. Kathleen Knafl, participated in the decisions made in the meeting through e-mail. After the expert committee meeting, the Portuguese Version 2 (PV 2) was established, in which all the items that contained the term chronic condition were changed to chronic disease to facilitate understanding of the items on the part of respondents. The term our child was also replaced by (child's name).

\begin{tabular}{|l|l|l|}
\hline \multicolumn{1}{|c|}{ Original version } & \multicolumn{1}{|c|}{ Portuguese version 1 } & \multicolumn{1}{c|}{ Portuguese version 2} \\
\hline $\begin{array}{l}\text { 6. Taking care of our child's condition is often } \\
\text { overwhelming. }\end{array}$ & $\begin{array}{l}\text { 6. Cuidar da doença de nosso filho é } \\
\text { frequentemente muito pesado. }\end{array}$ & $\begin{array}{l}\text { 6. Cuidar da doença de (nome da criança) é } \\
\text { frequentemente muito difícil. }\end{array}$ \\
\hline $\begin{array}{l}\text { 9. It is very hard for us to take care of our child's } \\
\text { condition. }\end{array}$ & $\begin{array}{l}\text { 9. Para nós é muito difícil cuidar da doença de } \\
\text { nosso filho. }\end{array}$ & $\begin{array}{l}\text { 9. É muito difícil para nós cuidar da doença de } \\
\text { (nome da criança). }\end{array}$ \\
\hline $\begin{array}{l}\text { 12. Our child's condition doesn't take a great } \\
\text { deal of time to manage. }\end{array}$ & $\begin{array}{l}\text { 12. Os cuidados com a condição do nosso filho } \\
\text { não requer muito tempo. }\end{array}$ & $\begin{array}{l}\text { 12. Lidar com a doença do (nome da criança) } \\
\text { não exige muito tempo. }\end{array}$ \\
\hline $\begin{array}{l}\text { 32. Many conditions are more serious than our } \\
\text { child's. }\end{array}$ & $\begin{array}{l}\text { 32. Outras crianças têm condições piores que a } \\
\text { do nosso filho. }\end{array}$ & $\begin{array}{l}\text { 32. Muitas doenças são mais sérias do que a do } \\
\text { (nome da criança). }\end{array}$ \\
\hline $\begin{array}{l}\text { 39. Our child would do better in school if he/she } \\
\text { didn't have the condition. }\end{array}$ & $\begin{array}{l}\text { 39. Nosso filho teria um melhor desempenho na } \\
\text { escola se não tivesse esta condição. }\end{array}$ & $\begin{array}{l}\text { 39. (nome da criança) poderia se sair melhor na } \\
\text { escola se não tivesse esta doença. }\end{array}$ \\
\hline
\end{tabular}

Figure 2 - Version presenting items changed after meeting with experts

The PV2 was sent to the back translation stage. There were no significant divergences in the two back-translated versions and the PV2 was kept as the instrument's Final Version.

In the Stage 2, we applied the FaMM adapted version to a sample of 72 families of children with chronic diseases.

The sample was composed of $60(83.3 \%)$ mothers, seven $(9.7 \%)$ fathers, three $(4.2 \%)$ grandmothers and two $(2.8 \%)$ others: a stepmother and an older brother.
In regard to education, 35 (48.6\%) reported nine or more years of schooling, 21 (29.2\%) reported from 5 to 8 years, and 16 (22.2\%) reported up to 4 years of schooling.

Of the studied families, $3.6 \%$ had other children and $25 \%$ did not have other children.

In regard to the families' income, 57\% reported their family income was sufficient, $34.7 \%$ reported they had insufficient income, and $8.3 \%$ reported that they have money left at the end of the month. When 
they were asked about their income before the child's disease, $63.9 \%$ of the family members answered their income was sufficient, $20.8 \%$ reported their income was already insufficient, and $15.3 \%$ reported that they had money left at the end of the month.

The children's average age was 6.39 years old (standard deviation $=3.99$ ). In regard to the child's sex, 41 (56.9\%) were male and 31 (43.1\%) were female.

As for the children's diseases, $29(40.3 \%)$ children presented progressive diseases, 29 (40.3\%) had stable diseases, and 14 (19.4\%) had recurrent diseases.

Due to the large diversity of chronic diseases among the children of the studied families, we opted to classify them into three groups according to the course of the disease: progressive, stable and recurrent diseases(17). In this classification, the conditions considered to be progressive are those that are always or generally symptomatic and generally present a worsening progression. An individual with a progressive disease continuously faces symptomatic effects and impairment increases gradually or progressively. The diseases considered to be progressive are: juvenile diabetes, hypothyroidism, and seizure syndromes, among others. Stable conditions are those that stabilize after disease onset. Diseases that present a stable course include cerebral palsy, thalassemia minor, intraventricular communication, and lactose intolerance. Recurrent or episodic diseases alternate stable periods, of varied duration in which there are few or no symptoms, with periods of exacerbation. Recurrent diseases include asthma, bronchitis and rhinitis ${ }^{(17)}$.

The descriptive statistics used for data analysis refer to the application of the FaMM's adapted version.

Table 1 - Descriptive statistics of the total scores by dimension and composition of Family Management Measure, Londrina, PR, Brazil, 2011

\begin{tabular}{|c|c|c|c|c|c|}
\hline Dimensions & $\mathbf{N}$ & Mean & Standard deviation & $(\min -\max )$ & Cronbach's alpha \\
\hline Child identity & 72 & 17.36 & 7.44 & $(3-25)$ & 0.7974 \\
\hline Management ability & 72 & 44.09 & 8.81 & $(17-60)$ & 0.5497 \\
\hline Management Effort & 72 & 14.12 & 4.45 & $(4-20)$ & 0.3636 \\
\hline Family difficulty & 72 & 29.97 & 12.95 & $(12-61)$ & 0.7815 \\
\hline Parental mutuality & 59 & 30.91 & 9.10 & $(8-40)$ & 0.7908 \\
\hline View of condition impact & 72 & 24.32 & 6.08 & $(12-42)$ & 0.4275 \\
\hline Total Score & & & & & 0.8660 \\
\hline
\end{tabular}

The highest mean obtained among the instrument's dimensions was Management Ability (44.09), though its internal consistency was only 0.549 (interval of 17- 60); a mean of 14.12 was obtained in Management Effort (interval of 4-20), while its Cronbach's alpha was not representative $(0.363)$; the best Cronbach's alpha was found in the dimension Child Identity (0.797) with a mean of 17.36 (interval of 3-25).

Table 2 - Coefficient of correlation of the items with the total Management Effort dimension and Cronbach's alpha, Londrina, PR, Brazil, 2011

\begin{tabular}{lccc}
\hline \multicolumn{1}{c}{ Item } & Sign & $\begin{array}{c}\text { Item-total } \\
\text { correlation }\end{array}$ & $\begin{array}{c}\text { Cronbach's } \\
\text { alpha }\end{array}$ \\
\hline 3 & + & 0.5090 & 0.3721 \\
7 & + & 0.6233 & 0.2129 \\
12 & + & 0.7089 & 0.1137 \\
35 & - & 0.5006 & 0.4430 \\
Dimension & & & 0.3636 \\
\hline
\end{tabular}

In the dimension Management Effort, as shown in the previous table, the Cronbach's alpha was 0.3636 , explaining only $36.3 \%$ of the variability of the phenomenon, which is not acceptable for the instrument's process of validation. Item 35 presented the lowest correlation with the total results of the dimension and its exclusion from the instrument would increase the Cronbach's alpha of the dimension to 0.4430 , explaining $44.3 \%$ of the phenomenon of variability of this dimension, and would be considered acceptable for the validation process.

\section{Discussion}

Among the 53 items of the instrument, all those that contained the term "chronic condition" were changed to "chronic disease" as suggested by the original instrument's author, which the experts agreed with in the meeting held to assess the translated instrument. This change was due to the fact that the Brazilian respondents would understand the term "chronic disease" better.

After the application of the translated instrument, we realized that the part that contained sociodemographic data was deficient. There was a lack of questions addressing the length of time since the child had been diagnosed, which is considered highly 
important when addressing family management. It is believed there is a relationship between the time since the disease was diagnosed and the adaptation of the family in the management of the condition. Over time, most families perceive themselves as more skillful in their reactions to treatment and how they deal with the disease in a way that minimizes disorganization caused by the disease in the family dynamics ${ }^{(18)}$.

It is estimated that only after the first six months of the disease diagnosis is the family able to resume its normal functioning ${ }^{(19)}$. At the beginning of the disease, the family is usually "unstructured"(18), therefore management styles change over time.

After the application of the instrument's adapted version to the above-mentioned population, we performed the descriptive analysis of the instrument's items. Cronbach's alpha was used to measure the internal reliability of the instrument's items, which was 0.8660 for the entire instrument, indicating that the instrument explains $86.6 \%$ of the phenomenon's variability. The values of Cronbach's alpha in the dimensions of Child Identity, Management Ability, Family Difficulty, Parental Mutuality and View of the Condition Impact were considered acceptable for the validation process.

The Management Effort dimension, however, obtained a Cronbach's alpha of 0.36 , which is not acceptable for the validation process. Cronbach's alpha is acceptable for the validation process when above $0.40^{(20)}$. Low internal consistency indicates that some of the instrument's individual characteristics may be measuring different characteristics ${ }^{(21)}$.

With the exception of the dimension Management Effort, the Cronbach's alpha values obtained by the adapted version are similar to those found in the original version, which shows the instrument has good internal consistency ${ }^{(14)}$. The original version obtained an internal consistency that ranged from 0.72 to 0.91 for all six dimensions ${ }^{(12)}$.

We observed during data collection that item 23 concerning the dimension Family Difficulty "(name of the child)'s condition rarely interferes with other family activities" was difficult for the respondents to understand and we believe that the word "rarely" was the cause of the difficulty. However, it was considered a positive item and obtained an alpha value of 0.44 and its exclusion would not change the instrument's or the dimension's alpha values.

Item 42 of the Family Difficulty dimension was translated into Portuguese as: "It is difficult to adapt the activity of taking care of our child's condition in our family routine" and after the meeting with the experts it was changed to: "It is difficult to adapt the (name of the child)'s care activities into the family routine." During data collection, however, we observed that the word "condition" affected the interviewees' answers. Most reported that care should be provided to any child and that families adapt to the care provided to their children regardless of any disease. Analysis of internal consistency of this specific item showed it did not obtain a satisfactory alpha for the item-instrument correlation (0.31) but neither did it interfere in the Cronbach's alpha of the entire instrument and its withdrawal was not justifiable.

Item 49 of the dimension Parental Mutuality "My partner and I discuss how to manage (name of the child)'s disease" is considered an inverse item and the best answer to the question would be "totally disagree". We observed, however, that some families that positively answered all the dimension's items, thus indicating good mutuality, on this question answered the opposite, indicating there was poor understanding of this specific item. We believe that the term "discuss" was interpreted as "reach a consensus," showing a positive aspect of the relationship.

In regard to the instrument's functional equivalence, we verified a satisfactory level of equivalence. The results of the adapted version seem to indicate good application and understanding of the instrument by the studied sample.

Given the results and considering this study's objectives, we verified that FaMM presents conceptual equivalence since it was relevant in all the study's stages. We note the importance of having instruments validated in Brazil to measure family management because only after identifying the nature of a family's dynamics can one provide integral care able to meet the needs of children and families. Further research is needed to more broadly explore and expand the concept of family management to other populations.

\section{Conclusion}

The FaMM's Portuguese version, the name of which in Portuguese is Instrumento de Medida de Manejo Familiar, revealed properties that certify its quality through conceptual, by-item, semantic, idiomatic, and operational equivalences, in addition to content validation, to assess the management of families of children with chronic diseases. 
The Cronbach's alpha used to measure the internal reliability of the instrument's dimensions showed reliability in five of the six dimensions when tested with a sample of Brazilian families of children and adolescents with chronic conditions. Only the dimension Management Effort did not show internal reliability and needs to be reassessed in the next stage of research.

The process of translation and adaptation of the Family Management Measure resulted in an instrument adapted to the Brazilian culture and enabled us to conclude that the pretest showed that the instrument is applicable in the Brazilian context and can provide data for future studies to compare information with international research. After the entire process of validation is concluded, that is, after the research project's final stage, this instrument will be able to assess how families manage the child or adolescent with chronic diseases.

A lack of other instruments measuring the management of children with chronic diseases hinders any deeper analysis of the instrument. Only with dissemination of knowledge on the subject will we be able to advance in research addressing measures of family management.

After FaMM validation is accomplished with a larger sample, which is currently being performed by the same group of researchers, we recommend its use in different populations in order to better represent the Brazilian situation in terms of family management.

\section{References}

1. World Health Organization. [Internet]. [acesso 15 dez 2009]. Disponível em: http://www.who.int/topics/ chronic_diseases/en/

2. Brown RT, Wiener L, Kupst MJ, Brennan T, Behrman

$\mathrm{R}$, Compas BE, et al. Single Parents of Children with Chronic Illness: An Understudied Phenomenon. J Pediatr Psychol. 2008;33(4):408-21.

3. Nascimento LC, Rocha SMM, Hayes VH, Lima RAG. Crianças com câncer e suas famílias. Rev Esc Enferm USP. dez 2005;39(4):469-74.

4. Lopes M, Stuhler GD. Atendimento psicológico a mães de crianças com doença crônica: relato de experiência. Psicol Argum. out/dez 2008;26(55):341-7.

5. Taylor RM, Faith G, Franck LS. The experience of living with a chronic illness during adolescence: a critical review of the literature. J Clin Nurs. 2008 Dec;17(23): 3083-91.

6. Guimarães TMR, Miranda WL, Tavares MF. O cotidiano das famílias de crianças e adolescentes portadores de anemia falciforme. Rev Bras Hematol Hemoter 2009;31(1):9-14.

7. Góis FGB, La Cava AM. Práticas educativas em saúde do enfermeiro com a criança hospitalizada. Rev Eletr Enferm. [Internet]. 2009 [acesso 25 maio 2013]; 11(4): 942-51. Disponível em: http://www.fen.ufg.br/ revista/v11/n4/v11n4a20.htm

8. Knafl K, Deatrick J. Further Refinement of the Family Management Style Framework. J Fam Nurs. 2003;9(3):232-56.

9. Bousso RS, Misko MD, Mendes-Castillo AMC, Rossato LM. Family Management Framework and Its Use With Families Who Have a Child Undergoing Palliative Care at Home. J Fam Nurs. 2011;18(1):91-122.

10. Knafl KA, Deatrick JA, Havill NL. Continued development of the family management style framework. J Fam Nurs. 2012 Jan;18(1):11-34.

11. Knafl K, Deatrick J. Family management style and the challenge of moving from conceptualization to measurement. J Pediatr Oncol Nurs. 2006 JanFeb;23(1):12-8.

12. Knafl K, Deatrick J, Gallo A, Dixon J, Grey M, Knafl G, $\mathrm{O}$ 'Malley J. Assessment of the Psychometric Properties of the Family Management Measure. J Pediat Psychol. 2011 May; 36(5):494-505.

13. Knafl K, Deatrick J, Gallo A. The interplay of concepts, data, and methods in the development of the family management style framework. J Fam Nurs. 2008 Nov; 14(4):412-28.

14. Guillemin F, Bombardier C, Beaton DE. Crosscultural adaptation of health-related quality of life measures: literature review and proposed guidelines. J Clin Epidemiol. 2002;25(24):3186-91.

15. Conselho Nacional de Saúde (BR). Resolução No 196, de 10 de outubro de 1996. Diretrizes e normas regulamentadoras de pesquisas envolvendo seres humanos. Brasília; 1996.

16 Polit DF, Beck CT. Fundamentos de Pesquisa em Enfermagem. Avaliação de evidências para a prática de enfermagem. 7a ed. Porto Alegre: Artmed; 2011.

17. Rolland JS. Doença crônica e o ciclo de vida familiar. In: Carter B, McGoldrick M. As mudanças no ciclo de vida familiar: uma estrutura para a terapia familiar. $3^{a}$ ed. Porto Alegre: Artes Médicas; 2007. p. 373-92.

18. Deatrick J, Thibodeaux A, Mooney K, Schmus C, Pollacki R, Davey B. Family management style framework: A new tool with potential to assess families who have children with brain tumors. J Pediatr Oncol Nurs. 2006; 23(1):19-27. 
19. Grey M, Knafl K, McCorkle R. A framework for the study of self-and family management of chronic conditions. Nurs Outlook. 2006;54(5):278-86.

20. Nunnaly JC. Psychometric Theory. New York: McGraw-Hill; 1978.

21. Cummings SR, Stwart A, Rulley SB. Elaboração de questionários e instrumentos de coleta de dados. In: Hulley SB, Cummings SR, Browner WS, Warren S, Grady DG, Newman T. Delineando a pesquisa clínica. Uma abordagem epidemiológica. $3^{a}$ ed. Porto Alegre: Artmed; 2008. p. 265-81. 